\title{
THE GROWTH OF INTENTION AS A RULE OF LAW
}

\author{
Albert Sidney Bolles
}

The greater freedom of the courts than formerly from artificial, technical rules unless restrained by a higher law than that of their own making, is one of the great changes everywhere seen in modern jurisprudence. Nevertheless, there are always difficulties in the way of juridical improvement. Thus in the early days of partnership transactions, the question arose, what is the test of a partnership? It was soon learned that one might act in such a way toward the outside world as to create a personal liability as partner, while in fact no such relation existed between him and his business associates. Leaving out the latter aspect of his position, what acts, or what kind of an agreement, creates a partnership liability to persons doing business with it? One of the most common tests was a division of the profits.

On some occasion a clerk was given a share of the profits as compensation for his services, and the concern afterward failed. Of course the creditors, who in such unlucky ventures always seek to obtain from the wreck everything they can, sought to hold him as a partner. Though he did not suppose he was one, nor did the partners, the courts, so much wiser than they, applied this rule to him and the poor fellow lost all he had. So in Pennsylvania it was long ago decided ${ }^{1}$ that a direct participant in profits, as profits, was a partner with respect to third persons, whatever arrangement might exist between himself and the partners. This was founded on the English case of Waugh $v$. Carver, ${ }^{2}$ which for a long period was the great landmark in this field of controversy. Our immediate interest lies in the reason on which the rule was founded. In an earlier case ${ }^{3}$ Chief Justice De Grey had announced the doctrine "that every man who has a share of the profits of a trade ought also to bear a share of the loss," the reason for which was given in Waugh v. Carver" that "he who takes a moiety of all profits indefinitely shall, by operation of law, be made liable to losses, if losses arise, upon the principle that by taking a part of the profits, he takes from the creditors a part of that fund which is the security to them for the payment of their debts." This reasoning seemed quite satisfactory to the judicial mind until dissolved by a stronger minded one with "the short answer," that the reason "was founded on a false assumption. Creditors neither can, nor do, rely on net profits for payment."'5

${ }^{1}$ Edwards v. Tracy (I869) 62 Pa. 374, 380.

2 (I793, C. P.) 2 H. B1. 235.

${ }^{3}$ Grace v. Snith (I775, C. P.) 2 W. B1. 998.

Stupra note 2, at p. 247, quoted with approval and followed in Purviance $v$. $M^{\prime}$ 'Clintee (r820, Pa.) 6 Serg. \& Rawle, 259, 26r.

${ }^{5}$ Smith, J., in Eastman v. Clark (1872) 53 N. H. $276,285$. 
Another reason holding that the profit sharer may be regarded by the business world as a partner is worth stating, because it emanated from that great legal luminary Lord Mansfield, though it has a still weaker foundation. Such a sharer of the net profits, he declared, might receive usurious interest without any risk. In those days usury was a crime, and therefore to preserve the receiver from breaking the usury law he was held as a partner. Poor fellow of a clerk who thus received as a return for his services a share of the profits; he was truly between the devil and the deep sea. ${ }^{6}$ Lord Mansfield's reasoning was severely criticised by Justice Lindley in his work on Partnership, ${ }^{7}$ while Judge Smith makes still shorter work of it, assertings that it "does not seem very forcible. Usury is punished by the refusal of the law to enforce usurious contracts, or by the imposition of penalties; but it is not customary to punish usury by compelling parties to perform contracts which they never made."

Notwithstanding the unreasonableness of this rule it has been maintained until a recent period in some states, the courts declaring that if a change were needed it was the duty of the legislature to act; in other states the courts have changed the rule moved by the more imperative demands of justice. In England Waugh $v$. Carver ${ }^{9}$ was overruled first by the courts, ${ }^{10}$ and afterward by statute. ${ }^{11}$

The early English rule was adopted by some of the American states, notably New York and Pennsylvania; ${ }^{12}$ after a time began the wavering. Some courts clearly saw that intention should play a larger part in determining the test, that justice required its application, and acted accordingly. Other courts just as clearly saw the way of justice but were overawed by the ancient rule of stare decisis. Judge Folger voiced this conception of judicial duty in the Leggett case. ${ }^{13}$ "If it is found that by a long course of decisions, or by long acquiescence in, and adherence to, a rule some time ago authoritatively promulgated, there has been established a principle of commercial law upon which the community has acted, it is the duty of the courts to adhere thereto, leaving it to the law-making power to find a remedy, if remedy be needed, in a positive alternative enactment." In sharpest contrast with this conception of his duty was that of Baron Bramwell in overruling Waugh v. Carver, declaring as he did so, ${ }^{14}$ that "it had caușed more injustice and mischief than any bad law in our books."

\footnotetext{
'Blothan v. Pell (1775, C. P.) 2 W. B1. 999.

7 (5th Eng. ed. I888) I6.

${ }^{8}$ Eastman v. Clark, supra note 5, at p. 286.

'Supra note 2.

${ }^{10}$ Cox v. Hickman (1860) 8 H. L. Cas. 268; see also: Bullenv. Sharp (1865)

L. R. I C. P. 86; Mollwo v. Coutr of Wards (I872) L. R. 4 P. C. 4 Ig.

${ }^{11} 28 \& 29$ Vict. c. 86.

${ }^{13}$ Leggett v. Hyde (1874) 58 N. Y. 272, citing the New York cases; Wessels \& Co. v. Weiss \& Co. (I895) I66 Pa. 490, 3I Atl. 247, citing the Pennsylvania cases. ${ }^{13}$ Supra note 12, at p. 277 .

${ }^{16}$ Bullen v. Sharp, supra note xo, at p. 128.
} 
Even after the old rule had been overthrown by the legislature in some jurisdictions it retained a latent power. Thus in 1870 the Pennsylvania legislature enacted that in lending money if a share of the profits was agreed in writing to be received in lieu of interest, the lender was not to be held as a partner. ${ }^{15}$ Yet the law has been so narrowly construed that it has been largely emptied of its meaning. ${ }^{16}$ Justice Fell in reviewing the long series of decisions founded on Waugh $v$. Carver clearly showed that the spell of that decision, notwithstanding the statute, was not yet broken. The entire legal beach is strewn with wrecked or greatly impaired statutes, driven ashore not by collision with great constitutional principles, but rather with common-law rules which courts have deemed the higher wisdom to maintain.

Let us now examine some of the cases in which the courts have not hesitated to apply the modern rule of intention to test the partnership relation. In Beecher v. Bush, ${ }^{17}$ Justice Cooley, speaking for the higher court of Michigan, declared that all the cases cannot be reconciled, and "show that, in so far as the notion ever took hold of the judicial mind that the question of partnership or no partnership was to be settled by arbitrary tests it was erroneous and mischievous, and the proper corrective has been applied. Except when one allows the public or individual dealers to be deceived by the appearances of partnership where none exists, he is never to be charged as a partner unless by contract and with intent he has formed a relation in which the elements of partnership are to be found. It is nevertheless possible for parties to intend no partnership and yet to form one. If they agree upon an arrangement which is a partnership in fact, it is of no importance that they call it something else, or that they even expressly declare that they are not to be partners. The law must declare what is the legal import of their agreement, and names go for nothing when the substance of the arrangement shows them to be inapplicable. But every doubtful case must be solved in favor of their intent."

It is worthy of note that three years before Cox v. Hickman ${ }^{18}$ was decided by the House of Lords the same view was maintained by the Supreme Court of Tennessee. ${ }^{19}$ Judge McKinney, after declaring the rule and adding that it was consistent with the great rule of construction-that all agreements are to be expounded according to the manifest intention of the parties-thus continued: ${ }^{20}$ "in all such cases it is a question of fact, open to proof in the ordinary modes, whether or not a partnership exists by the intention and agreement of the parties. And if the fact be clearly shown not to be so, a mere stipulation, that

${ }^{15} \mathrm{~Pa}$. Laws, I870, No. 34.

${ }^{10}$ Wessels \& Co. v. Weiss \& Co., supra note I2.

${ }^{17}$ (I88I) 45 Mich. I88, 200.

${ }^{28}$ Supra note 10.

${ }^{19}$ Polk v. Buchauan (1857) 5 Sneed, 721.

${ }^{20}$ Ibid. at p. 728. 
a party shall receive a specific proportion of the net or gross profits of a business; or, an ascertained amount, payable out of the profits. as a compensation for services, benefits, or advantages rendered to the business, will not make such party liable as a partner, to third persons; provided he has not permitted the use of his name; or suffered himself to be held out as a partner to the public." 21

When therefore a person shall receive a portion of the profits of a partnership as compensation for his services he is not a partner; but hardly had the courts solved that question before they encountered another quite as difficult to answer. At what stage of the business shall the profits be ascertained in order to escape liability as a partner? This question has been considered in many cases, and the brief answer given in Chapline v. Conant ${ }^{22}$ has been often approved-that unless one has some ownership in or of the profits as they accrue and are not ascertained or divided into portions or dividends, he is not a partner. ${ }^{23}$

Is not the view set forth in Parker v. Canfield ${ }^{24}$ still more satisfactory? Says Justice Seymour: "The mere use of the expression 'a sum equal to the profits' in lieu of the word profits does not change the nature of the contract. There are indeed cases where money secured may be regarded as a sum measured by profits rather than as profits themselves; but whether they shall be so regarded depends upon no arbitrary use of phrases, but upon the nature of the contract and the real consideration upon which the money is received."

The Uniform Partnership act provides that "the receipt by a person of a share of the profits of a business is prima facie evidence that he is a partner in the business, but no such inference shall be drawn if such profits were received in payment (a) as a debt by installments or otherwise, (b) as wages of an employee or rent to a landlord, (c) as an annuity to a widow or representative to a deceased partner, (d) as interest on a loan, though the amount of payment vary with the profits of the business, (e) as the consideration for the sale of the good-will of a business or other property by installments or otherwise." 25 Whether the legislator has succeeded more perfectly than the courts in solving this fresh problem is receiving daily answer.

Passing from the application of the rule of intention in partnership formation cases to those of the joint tort-feasors, a still wider and

\footnotetext{
${ }^{21}$ See also Cudahy Packing Co. v. Hibou (1908) 92 Miss. 234, 46 So. 73; Estabrook v. Woods (1906) I92 Mass. 499, 78 N. E. 538; Langley v. Sanborn (I908) I35 Wis. I78, II4 N. W. 787; see I Rowley, Partnership (I9I6) sec. 75; and elaborate discussion of the subject in Eastman v. Clark, supra note 5.

2 (1869) 3 W. Va. 507, 5I9.

${ }^{23}$ See discussion of the question by Wilder, J., in Demny v. Cabot (I843) 47 Mass. 82.

24 (1870) 37 Conn. 250, 267.

${ }^{23}$ Sec. 7 , ch. 4 .
} 
more confusing field lies before us. We may begin with the unquestioned rule that the injured person can receive only one satisfaction. ${ }^{26}$ There may also be a partial satisfaction from one or more of the tortfeasors, or from other persons, which operates pro tanto as a satisfaction against the other tort-feasors. ${ }^{2 \pi}$

Again a tort-feasor who has been released under seal is generally deemed to have rendered a complete satisfaction for the tort, as the seal has the magical effect of importing a consideration, whether it has been actually paid or not. ${ }^{28}$ In the Gunther case the Maryland Court expressed the rule as follows:" "As a consideration is always implied in a release under seal, though not expressed on its face, the release by deed of one joint trespasser will discharge all, and this has been the law since early times." This rule is so artificial that its hoary antiquity has not preserved it from modern attack as will be seen before concluding this article.

Let us now glance at the artificial motive of a joint tort. Long ago Chief Justice Hosmer said:"30 "If a trespass is committed by $A$ and $B$ on the body of another, the acts are distinct. The stroke of $\mathrm{A}$ in fact, not being the stroke of $\mathrm{B}$; and vice versa. But, by operation of law, these distinct acts are amalgamated, and, in all their parts, become the united act of both." "The indivisibility of a tort, committed by two or more persons, is therefore a mental creation, having no foundation in fact. The courts have transformed this mental creation into a judicial one, and by so doing, have blocked up their road with an imaginary mountain. Had they kept clearly in sight the plain rule that there could be one satisfaction, and one only, coming to the injured party, no matter from what source, and that this could be given partly by one, partly by another, the courts would have escaped many of their difficulties. ${ }^{31}$ Thus in Gilpatrick v. Hunter, a case often cited, the court declares" that as the tort is joint there "can be no separate

\footnotetext{
${ }^{25}$ For cases see 92 Am. St. Rep. 873, note; I Jaggard, 'Torts (I895) sec. II7 et seq.

${ }^{27}$ Lovejoy v. Murray (I865) 70 U. S. I; Gunther v. Lee (I876) 45 Md. 60, 67; Knapp v. Roche (I884) 94 N. Y. 329, 334; Livingston v. Bishop (I806, N. Y.) I Johns. 290; Chamberlin v. Murphy (I868) $4 \mathrm{I}$ Vt. IIo, II8; Eastman v. Grant (I86I) 34 Vt. 387, 390; Randall v. Gerrick (Igr6) 93 Wash. 522, I6I Pac. 357; Kropidlozeski v. Pfister Leather Co. (I9I2) I49 Wis. 42I, 423, I35 N. W. 839, 840; Ellis v. Esson (1880) 50 Wis. I38, citing many cases.

${ }^{23}$ Allen v. Ruland (1906) 79 Conn. 405, 65 Atl. 138; Gunther v .Lee, supra note 27; Bronson v. Fitzhngh (I84I, N. Y.) I Hill, I85; Irvine v. Millbank (I874, N. Y.) I5 Abb. Pr. (N. s.) 378; Brozen v. Marsh (I835) 7 Vt. 320, 327; Bloss v. Plymale (1869) 3 W. Va. 393, 405; Ellis v. Esson, supra note 27, at p. 146.

${ }^{29}$ Gunther v. Lee, supra note 27 , at p. 67.

${ }^{30}$ Sheldon v. Kibbe (1819) 3 Conn. 214, 220.

${ }^{32}$ See Dwy v. Comecticut Co. (1914) 89 Conn. 74, 92 At1. 883, containing a most thorough discussion of the subject.
}

${ }^{32}$ (I844) 24 Me. I8, I9. 
estimate of the injury committed by each and a recovery accordingly ..... The difficulty in maintaining the suit against the others is, that the law considers, that the one, who has paid for the injury occasioned by him, and has been discharged, committed the whole trespass and occasioned the whole injury, and that he has therefore satisfied the plaintiff for the whole injury, which he received." The court, therefore has transformed its first theory that an indivisible joint tort was committed, which cannot be divided, into another theory that a joint tort was not committed, but that it was a single tort committed by the one who paid for it. But how utterly opposed to fact are these theories in most cases? No wonder that the courts from an early period sought to escape from them. We may now begin with the English rule. This will not detain us long for the work has already been done by a master hand. Mr. Justice Miller, in Lovejoy v. Murray, after showing that the English courts had been shifting around like a lost sailor at sea prior to the decision in Broome v. Wooton, ${ }^{33}$ adds $^{34}$ that even now after several later attempts to establish a rule, "we are forced to the conclusion that even at this day the doctrine there is neither well settled nor placed on any satisfactory ground." This utterance was nearly sixty years ago. Since that time the English courts have continued to wrestle with the question and in Gilbert v. Finch Judge Haight, speaking for the New York Court of Appeals, said:35 "In England the modern authorities appear to be quite uniform upon the question. They are to the effect that, as between joint-debtors and joint tort-feasors, a release given to one releases all; but if the instrument contains a reservation of a right to sue the other joint-debtors or tort-feasors, it is not a release, but, in effect, is a covenant not to sue the person released, and a covenant not to sue does not release a joint-debtor or a joint tort-feasor."

Turning now to the American rule Judge Haight showed that the stream of judicial decision had not always flowed in a uniform current. Chancellor Kent stairted right in Kirby $v$. Taylor ${ }^{3 B}$ by holding that a release was to be construed according to the clear intention of the parties, and if it contained a reservation, the other obligee was not discharged. Instead of following this rule the court wandered off, but returned in the Whittemore case, ${ }^{37}$ Judge Brown declaring that equity always gives to a release operation according to the intention of the parties and the justice of the case. The legal rule applied by the courts of law had been otherwise, he admitted, and that a saving clause repugnant to the nature of the grant had been held void and the grant still

\footnotetext{
${ }^{3}$ (I606, K. B.) Yelverton, 67.

3L Lovejoy v. Murray, supra note 27, at p. I4.

s (I903) I73 N. Y. $455,463,66$ N. E. I33, I35.

so (I822, N. Y.) 6 Johns. Ch. 242, 253.

${ }^{27}$ Whittenore v. Judd Oil Co. (189r) 124 N. Y. 565, 27 N. E. 244.
} 
remained absolute and unqualified. Such is not the modern rule of construction. The rule now held is thus stated: $:^{38}$ "The equitable rule now prevails and a release is to be construed according to the intent of the parties and the object and purpose of the instrument, and that intent will control and limit its operation."

While this is the prevailing rule and in harmony with the best reason, the older rule growing out of the indivisibility of a tort is still competing with the other for judicial acceptance in other jurisdictions. One of the earlier applications was in Ruble $v$. Turner. ${ }^{39}$ The discharge in that case contained the reservation that the sum paid by the one who was released "should not be considered as in satisfaction" in favor of the other tort-feasors. Nevertheless the court, in answer to the question, what is the effect of the clause in this instrument in writing, thus delivers itself: "The law [the italics are those of the court] says, that if one joint trespasser be released, or make accord and satisfaction, it shall bar a recovery against all the others. The plaintiff can no more change the law, in this particular, by any subsequent proviso or condition, than he could, after a grant in fee simple, by deed, restrain his grantee from selling the lands. ... The proviso then is merely void, and cannot prevent the legal effect of the accord and satisfaction made by one of the defendants." This reasoning is followed in many of the subsequent cases releasing the other tort-feasors. This case is more radical than the succeeding ones in this respect-that the discharge was not under seal, and therefore the rule of construction invoked by Judge Tucker" "that if there be any clause or condition in a deed, which is either contrary to law, or repugnant to the nature of the estate created, it is void"-hardly applies because the controversy in writing was not a deed, and no consideration expressing a complete satisfaction could be implied because there was no seal. Moreover it may be noted that Chief Justice Marshall in Garnett $v$. Macon ${ }^{4 \mathrm{x}}$ at circuit wholly ignored the decision and took precisely the opposite view. ${ }^{42}$ McBride v. Scott, ${ }^{43}$ in which the court squarely held that a release of one or more joint tort-feasors releases the others, although there be an agreement in writing that they should not be discharged, states a rule that has been often followed. ${ }^{44}$ In the way of fortifying its

${ }^{3}$ Ibid. at p. 574,27 N. E. at p. 245 .

${ }^{39}$ (1808, Va.) 2 Hen. \& Munf. 38, 44

${ }^{10} \mathrm{Ibid}$. at p. 44 .

¿1 (I825, So. C.) 2 Brock. I85, Io Fed. Cas. I2.

"See McDonald v. Goddard Grocery Co. (I9r4) I84 Mo. App. 432, 439, x7I S. W. 650,653 .

${ }^{43}$ (1903) I32 Mich. 176, 93 N. W. 243.

"Semlin v. Skutt (1903) I33 Mich. 208, 94 N. W. 733; Gilpatrick v. Hunter (1844) 24 Mo. 18; Brogan v. Hanan (1900) 55 App. Div. 92, 66 N. Y. Supp. 1066; Mitchell v. Allen (188I, N. Y.) 25 Hun, 543; Ellis v. Bitzer (I825) 2 Ohio, 89; Brown v. Kencheloe (I866, Tenn.) 3 Cald. I92. 
opinion the court declared ${ }^{45}$ that to admit of a settlement with one tort-feasor under such circumstances there presented, and to hold that a reservation such as was there attempted to save the right as to the tort-feasors, "would open the door for the plaintiff in any case to acquire by successive settlements more than just compensation." What becomes of the great rule, the potency of which none will dispute, that the injured party is entitled to and can have only one satisfaction? The court also had another fear if a different rule were adopted which had been previously expressed by the court in Browen v. Kencheloe ${ }^{46}$ that the plaintiff in many instances "would operate upon the fears of the defendants, and get from each the full amount of the trespass committed." Fears! but surely their fears would be slight compared with the absolute cutting off by the courts of the right of the injured party to proceed against all the wrongdoers to obtain satisfaction.

A few more cases will be briefly mentioned, because they are recent and show the persistency of some courts to continue to float their decisions on the old water-logged theories. California ${ }^{47}$ is grimly resisting the strong current of judicial decision in lonely company with the courts of Colorado ${ }^{48}$ and Washington. In Abb v. Northern Pacific $R y .{ }^{49}$ the Michigan doctrine was declared to be the law of the latter state. This case goes a little further than any of the others we have reviewed. The courts of California, undaunted by 'the strength of the current against them, still continue to head upstream. Their courage has been displayed in several cases, notably in the Chetwood case, ${ }^{50}$ and still more recently in Flynn $v$. Morrison. ${ }^{51}$ As a petition to have this cause heard by the Supreme Court was denied, the decision is conclusive of the law in that state. ${ }^{52}$

The old rule worked such manifest injustice that the courts at an early day found a way of circumventing it. Though still clinging to the doctrine that if the discharge were under seal this imported a full satisfaction-an artificial rule that will be further considered-when the discharge was not under seal, the courts did not hesitate to hold that the intention of the parties must govern. And if the discharge contained a reservation, whereby one or more of the joint tort-feasors was not released, the writing was held to be simply a covenant not to

\footnotetext{
${ }^{45}$ McBride v. Scott, supra note 43 , at p. 182,93 N. W. at p. 245.

${ }^{40}$ Supra note 44, at p. 200.

"See notes 50 and $5 \mathrm{I}$, infra.

4s Ducey v. Patterson (1906) 37 Colo. 216, 86 Pac. 109.

* (I902) 28 Wash. 428, 68 Pac. 954; cf. Randall v. Gerrick (1916) 93 Wash. 522, I6I Pac. 357; Betcher v. Kunz (1920, Wash.) I92 Pac. 954.

${ }^{\circ}$ Chetwood v. California Nat. Bank (I894) II3 Calif. 4I4, 45 Pac. 704; cf. Urton v. Price (I88I) 57 Calif. 270.

51 (1912) 19 Calif. App. 400.

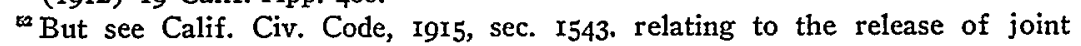
debtors, and Brown v. Pacific Coast Agency (rg2r, Calif.) 200 Pac. 977.
} 
sue the party released, thereby not impairing in any way the rights of the party injured to proceed against the other tort-feasors.

It will be observed that in applying the prevailing rule, whereby the discharge operates as a covenant or agreement not to sue the releasee, the indivisibility of the tort is ignored as completely as its invisibility; the thing kept before the judicial mind is the satisfaction. If there has not been a satisfaction, or only a partial one, then the injured party, unless he has actually and intentionally discharged the others, may proceéd against them to obtain complete satisfaction. In the $A b b$ case $^{53}$ the court went still further and held that "when an injured party makes an estimate of the amount of damages he is willing to receive from one, and accepts such sum with the agreement that it shall fully release and discharge the one making the payment, we think it is more than a mere agreement not to sue. It is a release of his cause of action in consideration of a satisfaction." Such an agreement may indeed be a satisfaction and release of the person rendering it, but why should it operate as a satisfaction from, and discharge of, the others when the releasor says as plainly as it can be said in words that he intends to hold them.

In the Gunther case $^{54}$ the discharge worked the release of all parties because it was under seal, which had the magical effect of being a complete satisfaction, though the parties certainly did not intend that it should thus operate. But the court said it did, and the intention of the parties was not permitted to overcome the rule of law. With this as a correct statement of the law no one will question that "as a consideration is always implied in a release under seal, though not expressed on its face, the release by deed of one joint trespasser will discharge all." Concerning this, however, two remarks are in order. First, if the discharge had not been under seal, the consideration would not have been regarded as a complete satisfaction. By adding a seal, and thereby giving too much solemnity to the writing, the releasor defeated the very end he had in view, of getting a partial satisfaction from one of the parties and further satisfaction from the others. Secondly, the court threw to the winds that great rule of construction, which applies to sealed writings as well as to others-that the whole instrument should be considered and that construction adopted which is most consistent with its apparent intent. And also another great rule-that if a deed contains two clauses repugnant to each other, the last will prevail. But, if possible, the repugnant provision should be so construed as to reach the true intention of the parties, and to accomplish this purpose the deed should be considered as a whole. ${ }^{55}$ The court threw overboard the reservation as surplusage because it contradicted the

${ }^{6}$ Supra note 49 , at p. 438 .

- Supra note 27.

${ }^{\omega_{2}}$ Devlin, Real Property and Deeds (3d ed. I9II) sec. 843a. 
first part of the writing, which stated in effect that there had been a complete satisfaction, and of course, if that were so, no more could justly be exacted. But if the general rule of construction above noted had been applied it was manifest from the reservation that there had been no complete satisfaction, and why should the consideration received be held to mean so much more than the parties intended? It is by giving such an undue sanctity to seals, endowing them with a meaning and force never intended by the users in many cases, that has led to the modification of their effect by statute as well as by judicial decision.

The courts generally have regarded written discharges either as technical releases, or as agreements not to sue. In nearly all cases in which the releasor has discharged all, this result has been accomplished because the satisfaction was deemed to be complete. Whatever we may think of the artificial character of a seal, this rule has been consistently maintained in the cases under review. Nevertheless we are justified in remarking on the irrational character of the rule. For surely it is an arbitrary thing to cut off the reservation in such a paper in violation of the great rule of construction applying to intent. And, if permitted to remain, no contradiction is apparent, and the truth then clearly appears that the consideration stated in the first part was not a full satisfaction, and was not intended to be, but only, that portion, great or small, which the releasor intended to exact from the party released. The repugnancy which is discovered by the judicial eye is of his own creation, an imaginary thing, having in truth no existence, caused by construing the instrument contrary to the plain intent of the makers.

Most of the discharges judicially investigated have not been sealed, and in construing these the rule may thus be stated: When it is evident that the consideration paid to the plaintiff was not intended to be a full compensation for his injuries, and the agreement signed by him, although in the form of a release, was clearly intended to preserve the liability of those who were not parties to it, many of the courts have sought to give effect to that intention by construing the agreement as in legal effect a covenant not to sue the person or persons released, the releasor thereby not impairing his right to pursue those who are not released. ${ }^{58}$ In the Musolf case $^{5 \tau}$ Justice Taggard has remarked

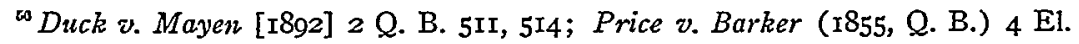
\& B1. 760,777 ; Carey v. Bilby (1904, C. C. A. 8th) I29 Fed. 203,63 C. C. A. 36r ; Young v. Anderson (Ig2I) 33 Idaho, 522, I96 Pac. I93; Chicago v. Babcock (I892) I43 I1l. 358, 32 N. E. 27 I Chicago \& Alton Ry. v. Averill (I906) 224 I11. 516, 79 N. E. 654; Renner v. Model Laundry Co. (1921) I9I Iowa, 1288, 1304, I84 N. W. 6rI, 6r8; Edens v. Fletcher (I908) 79 Kan. I39, 98 Pac. 784; Feighley v. Hoffman \& Son Milling Co. (I9I7) roo Kan. 430, I65 Pac. 276; Mathesonv. O'Kane (I9I2) 2I I Mass. 9I, 95, 97 N. E. 638, 639-640; Johnson v. Von Scholley (I9I4) 218 Mass. 454, 106 N. E. I7; Musolf v. Duluth Electric Co. (Igog) 108 Minn. 369, 375, I22 N. W. 499, 501-502; McDonald v. Goddard Grocery Co.
} 
that the principal controversy is not over the rule itself, whether it is a release working the discharge of all, or a covenant not to sue and excluding those mentioned and still holding them liable, "but the means by which a covenant not to sue is to be distinguished from a release." If the general rule of interpretation was applied to the usual paper with a reservation, as was done in the Drey case, ${ }^{58}$ there would be no such difficulty. The difficulty is created by the court that ignores it. Justice Taggard contends that if "a given instrument is" in law a release, it is not material that the parties agreed that it shall not be a release." But should the court say that in law a paper is a release when the parties say in words as plainly as they can use that they did not intend it to release the wrongdoers who are specified? What is the overwhelming necessity of having the lave, made and declared by the court, override the intention of the parties since the foundation on which the rule rests is nothing but a congeries of legal theories having no foundation whatever in fact, but contrary to it? Justice Taggard therefore does not hesitate to knock out the reservation just as would be done with a clause in a partnership agreement affirming that the members were not to be declared partners: But the analogy is not felicitous, for the partnership clause is knocked out, not because it is contrary to the intention of the parties, but because it is not honest to permit the parties to deny their partnership liability when they are really partners. By construing the ordinary discharge of a joint tort-feasor according to the intention of the parties justice is done to all of them. Why should a forced artificial construction be permitted to prevail over such a desirable result?

We cannot forbear a restatement of the general rule by the Supreme Court of West Virginia, that:59 “. . . A release not under seal of one joint trespasser or a satisfaction and discharge of the liability against him, which shows on its face that it was not the intention to satisfy and discharge the liability of the other joint trespassers will not, and cannot, be allowed to work a discharge of the action. In other words that a contract or agreement not unlawful in itself and plain and express in its terms, shall not be construed, nor made to defeat the object and intention of the parties, and much less to work a result they sought to avoid." To this may be added the remark of the Supreme Court of

(I9r4) I84 Mo. App. 432, I7I S. W. 650; Stachlin v. Hochdoerfer (rg2r, Mo.) 235 S. W. I060; Irvine v. Millbank (1874) 56 N. Y. 635; Gilbert v. Finch (1903) 173 N. Y. 455, 66 N. E. I33; Walsh v. New York Central Ry. (Ig12) 204 N. Y. 58, 97 N. E. 408; German American Coffee Co. v. O'Neil (Igr8, Sup. Ct.) IO2 Misc. 165 , 169 N. Y. Supp. 421 ; Nashlville Interurban Ry. v. Gregory (1916) 137 Tenn. 422, 435, т93 S. W. I053, I056; Bloss v. Plymale (1869) 3 W. Va. 393 ; Ellis v. Esson ( 1880 ) 50 Wis. I38.

${ }^{57}$ Musolf v. Duluth Electric Co., supra note 56, at p. 375, I22. N. W. at p. 502.

${ }^{85}$ Dey v. Connecticut Co. (I9I4) 89 Conn. 74, 92 Atl. 883 .

${ }^{\circ}$ Bloss v. Plymale, supra note 56 , at p. $40 \%$. 
Tennessee:": "It is difficult to see how a simple covenant not to sue one tort-feasor could affect or reduce the liability of another tortfeasor." The theory of the indivisibility of a joint tort did not disturb the court; indeed in many of the later cases it is not mentioned, and its uncomfortable presence is evidently fading out of the judicial mind. As the court said in that case, the important thing is for the courts to aid the injured person in obtaining complete satisfaction and nothing more.

Suppose a release or discharge contains no reservation? It then operates to discharge all the joint tort-feasors. This is the answer by the highest court of New York, ${ }^{61}$ and probably expresses the general rule.

In strong contrast with the modern course of the courts to ascertain the intention of the releasor in joint tort cases and to give effect to it and thereby administer justice, is the course of the courts in a long line of cases wherein the parties have predetermined the amount of damages accruing from the non-performance of their contracts. In many of these the intention of the parties as expressed in their agreements are as deliberately set aside by the courts in the interest of justice as they have been ascertained and enforced in the class of cases we have just reviewed. The legal morass on which we shall now briefly look is far more extensive than the other, and the desire of the courts to ascertain and enforce the rights of the parties has been no less clearly displayed.

In the earlier administration of the common law, when the parties had stipulated in advance for the payment of a specified sum in the event of the non-performance of a contract, the courts left the parties to their own devices and enforced them quite the same as other contracts regardless of consequences to all concerned. The hardships were so apparent that equity and Parliament came to the rescue of sufferers and granted relief whenever manifest injustice would be wrought by compelling the rigid enforcement of the intention of the parties in such cases. ${ }^{62}$

A stipulated sum may be and often is specified as damages which a party must pay if he fails to perform his contract. Nevertheless, if he does fail, can he be compelled to pay this sum which he has specified himself, or is this to be regarded as a penalty for his failure? For, whenever the later view prevails, then he is required to pay only so much as justice shall require, that is, to make the injured party good for the loss he has sustained. This view clearly implies an investiga-

${ }^{\infty}$ Nashville Interurban Ry. v. Gregory, supra note 56 , at p. 436,193 S. W. at p. 1056.

${ }^{0}$ Gilbert v. Finch, supra note 56 , at p. 466,66 N. E. at p. 136; Walsh v. New

York Central Ry. supra note 56, at p. 63, 97 N. E. at p. 410.

See 2 Williston, Contracts (I920) sec. 775. 
tion by the court and if need be the virtual remaking of the contract in controversy.

One would think that words mean something, and therefore when a party promises to give a sum, which he fixes himself, should he fail to execute his promise, he ought to fulfill it unless prevented by satisfactory reasons. Nevertheless, "though the intention of the parties seems clear and manifest that a breach shall operate as a complete forfeiture of the entire sum named in the agreement, the court will decline to lend its assistance to enforce the payment of an amount which is grossly excessive, unreasonable and unjust, and will treat the stipulation as in the nature of a penalty, and will award only such damages as the injured party may have actually sustained." ${ }^{63}$ Thus have the courts spoken many times. "Such a stipulation," said Barclay, P. J., in May v. Crawford," "is theoretically against the policy of the law as declared by the courts, which have established a supervision of agreements by a long course of precedents and acquiescence by the people therein." 65

The courts are quite harmonious in holding that in applying the rules of construction to such contracts, whatever they may be, is the work of the courts. The earlier doubt shown by some courts has passed away. ${ }^{\text {s8 }}$

Let us now state some general principles that may be applied to contracts of this character. First, may be eliminated all cases of fraud, mistake, circumvention, or oppression. ${ }^{67}$ Second, may be cut off all cases in which the stipulated amount of damages is grossly extravagant and disproportionate to the amount of the loss. The federal rule defining these is quite in harmony with the rule declared by the state jurisdictions. ${ }^{68}$ Third, "... . a stipulation to pay a specified sum upon the non-performance of a contract, is regarded as a penalty, rather than as liquidated damages, if the intention of the parties as to its effect, is at all doubtful, or is of equivocal interpretation. . . The tendency of late years has been to regard the statements of the parties as to liquidated damages in the light of a penalty unless the contrary intention is unequivocally expressed, so that harsh provisions will be avoided,

Sanders v. Carter (I893) gr Ga. 450, 453, 17 S. E. 345, 346.

(I898) I42 Mo. 390, 401, 44 S. W. 260, 262.

* For cases see $108 \mathrm{Am}$. St. Rep. 48 , note; and 2 Williston, op. cit. supra note 62 , sec. 778 .

${ }^{\circ}$ Pacific Factor Co. v. Adler (r8gr) go Calif. Iro, 27 Pac. 36; May v. Crawford (1899) I50 Mo. 504, 532, 5I S. W. 693, 70I; McMillan v. Bowie Nat. Bank (Ig09) 56 Tex. Civ. App. 45, IIg S. W. 709; Norman v. Vickery (IgI0) 60 Tex. Civ. App. 449, I28 S. W. 452; Kollaer v. Puckett (I92I, Tex. Civ. App.) 232 S. W. 9I4.

"Sun Printing \& Publishing Assn. v. Moore (I90I) I83 U. S. 642, 669-670, 22 Sup. Ct. 240, 25I; Dakin v. Williams (1837, N. Y.) 17 Wend. 447, 454, and (1839, N. Y.) 22 Wend. 2or.

${ }^{e 8}$ For cases see 108 Am. St. Rep. 52, note. 
and compensation alone will be awarded." 69 Fourth, when the damages in a case are uncertain in amount and are not readily susceptible of proof under the rules of evidence, and the parties have agreed upon a sum as the measure of compensation for a breach of the agreement, and that sum is not disproportionate to the presumable loss, it may be recovered as liquidated damages. ${ }^{70}$ Fifth, in cases wherein the actual damages do not differ greatly from the amount stipulated, the stipulated sum will be upheld as the legal measure that may be recovered. In these cases therefore the intention of the parties is executed. The variation between the actual damage and the stipulated amount is not great enough to set aside the expressed intention. ${ }^{71}$

In the sixth class of cases the variation in amount between the actual damage and the stipulated amount in the writing is more serious, is much larger. In dealing with these cases the federal and state courts part company. The federal courts quote with approval the view of Chief Justice Nelson declared in Dakin v. Williams" - that "A court of law possesses no dispensing power, it cannot inquire whether the parties have acted wisely or rashly, in respect to any stipulation they may have thought proper to introduce into their agreements. If they are competent to contract within the prudential rules the law has fixed as to the parties, and there has been no fraud, circumvention or illegality in the case, the court is bound to enforce the agreement." Some of the state courts also maintain this view.

The federal rule has been declared in several recent cases. In the Bethlehem Steel case, Mr. Justice Peckham said:"3 "The courts at one time seemed to be quite strong in their views and would scarcely admit that there ever was a valid contract providing for liquidated damages. Their tendency was to construe the language as a penalty, so that nothing but the actual damages sustained by the party aggrieved could be recovered." The old rule has been so modified that the courts will

${ }^{\oplus}$ Willson v. Mayor \& City Conncil (1896) 83 Md. 203, 2II, 34 Ati. 774, 775; cf. Mt. Airy Milling \& Grain Co. v. Runkles (I9I2) II8 Md. 371, 84 Atl. 533; Stratton v. Fike (Ig09) I66 Ala. 203, 5x So. 874; see 2 Williston, op. cit. supra note 62 , sec. 788 .

${ }^{70}$ Monmouth Park Assn. v. Wallis Iron Works (1892) 55 N. J. L. I32, I4I, 26 Atl. I40, I43; City of New Britain v. New Britain Telephone Co. (Ig02) 74 Conn. 326, 333, 50 At1. 881, 884, and cases cited; Banta v. Stamford Motor Co. (1914) 89 Conn. 51, 92 Atl. 665; Hemessy v. Metzger (1894) 152 I1l. 505, 38 N. E. 1058; Weiss v. United States Fidelity Co. (I92I) 300 Ill. II, I32 N. E. 749.

${ }^{71}$ Mansur Implement Co. v. Tissier Arms Co. (1903) I36 Ala. 597, 33 So. 818; Keeble v. Keeble (I888) 85 Ala. 552, 557, and cases cited; Leee v. Overstreet (I87x) $44 \mathrm{Ga} .507$; St. Louis Ry. v. Shoemaker (1882) $27 \mathrm{Kan} .677$; Noble v. Sturm (I920) 210 Mich. 462, I78 N. W. 99 ; Mason v. Callender (I858) 2 Minn. 350; Hill v. Wertheiner-Swarts Shoe Co. (r889) I50 Mo. 483, 5I S. W. 702.

${ }^{2}$ Supra note 67, I7 Wend. at p. 452 .

${ }^{73}$ United States v. Bethlehem Steel Co. (1907) 205 U. S. 105, II9, 27 Sup. Ct. 450,455 . 
now try to ascertain what agreement the parties have made, "to ascertain what their intention was when they inserted such a stipulation for payment, of a designated sum or upon a designated basis, for a breach of a covenant of their contract, precisely as they seek for the intention of the parties in other respects." The court, in a later case, speaking through Mr. Justice Clarke, says: :" "When that intention is clearly ascertainable from the writing, effect will be given to the provision, as freely as to any other, where the damages are uncertain in nature or amount or are difficult of ascertainment or where the amount stipulated for is not so extravagant, or disproportionate to the amount of property loss, as to show that compensation was not the object aimed at, or as to imply fraud, mistake, circumvention or oppression."75

In clear opposition to this view is another which has been stated by Judge Christiancy, speaking for the Supreme Court of Michigan, whose words have been often quoted with approval: "The law, following the dictates of equity and natural justice, in cases of this kind, adopts the principle of just compensation for the loss or injury actually sustained; considering it no greater violation of this principle to confine the injured party to the recovery of less, than to enable him, by the aid of the court, to extort more. It is the application in a court of law, of that principle long recognized in courts of equity, which, disregarding the penalty of the bond, gives only the damages actually sustained."76 The italics are those of the court and bring out still more clearly, if possible, that the ascertainment and enforcement of justice in this class of cases is the paramount idea in the judicial mind.

In applying these rules it may be noted that wherever the federal rule prevails, no distinction is drawn between the last three rules; all are regarded as a single rule that must be applied whenever the intention of the parties to the agreement must be carried out. The parties having made a lawful agreement, the courts will not undo their work and make another for them on the supposition they did not know what they were about, or that the court can act more wisely for them than they can act for themselves. In thus deciding the courts are also moved by the idea, if not always expressed, that if the parties acted hastily, thoughtlessly, so long as no fraud was lurking around, they ought to pay the cost, even though it be a heavy one, for thus acting without proper deliberation. This reasoning perhaps may seem to possess still greater force when it is remembered that many of the writings are drawn by lawyers who well know the rules of the law that apply

${ }^{74}$ Wise v. United States (I9I9) 249 U. S. 36I, 365, 39 Sup. Ct. 303, 304.

${ }^{3}$ Jewett, Bigelow \& Brooks v. Detroit Edison Co. (I92I, C. C. A. 6th) 274 Fed. 30. Certiorari was denied. Detroit Edison Co. v. Jewett, Bigelow \& Brooks (I92I) 257 U. S. 64I, 42 Sup. Ct. 52.

${ }^{76} J a q u i t h$ v. Hudson (1858) 5 Mich. 123, 133. For later Michigan cases, see Calbeck v. Ford (I905) I40 Mich. 48, 103 N. W. 516; Ross v. Loescher (1908) I52 Mich. 386, I16 N. W. I93; Noble v. Sturm, supra note 7I. 
to the terms of penalties and stipulated damages. There is, however, a different way of looking at parties and lawyers at the time of drawing these instruments that will be soon noticed.

Again, a doubt may be raised whether there is enough difference between the rules above given to constitute distinct rules of interpretation and application. How great must be the disproportion between the actual and stipulated damage in a given case to lead a court to disregard the rule of intention and apply the rule of justice to it. The best answer is found in a study of the cases.

Let us now inquire into the course of the state jurisdictions in applying these rules. The deliverance of Chief Justice Nelson in Dakin $v$. Williams, ${ }^{77}$ quoted with approval by Mr. Justice White, ${ }^{78}$ cannot be regarded as an expression of the existing New York rule, whatever be the force given to it as a federal opinion. It is true that in a later case the Court of Appeals, speaking through Judge Wright, did say:79 "When the parties to a contract in which the damages to be ascertained, growing out of a breach, are uncertain in amount, mutually agree that a certain sum shall be the damages in case of a failure to perform, and in language plainly expressive of such agreement, I know of no sound principle or rule applicable to the construction of contracts, that will enable a court of law to say that they intended something else." But he adds: "Where the sum fixed is greatly disproportionate to the presumed actual damages, probably a court of equity may relieve." This case from the legal point of view sustains the federal rule, but viewed in the light of equity sustains the rule of justice. This distinction must be kept in mind in studying the older cases where chancery iurisdiction prevailed.

The later New York view is, we think, embodied in Perley $v$. Schubert, ${ }^{80}$ in which the court, after remarking that the counsel had cited "a multitude of cases" to assist the court in determining whether the clause in the controverted agreement was to be interpreted as liquidated damages or a penalty, and that "all of these cases and many more" had been examined by the court, conclude: "From them has been deduced one rule, at least, in which they all agree, and about which there can be no doubt, and that is, that in the construction of such provisions the actual intention of the parties, so far as it can reasonably and fairly be ascertained from the language of the contract and from the nature of the surrounding circumstances, is to be considered; in other words, that each case is to be considered in the light of its own facts."

In a well considered case of earlier date, the court took a similar view. "In the earlier cases," said Justice Agnew, "the courts gave more

"Supra note 67, i7 Wend. at p. 449.

${ }^{78}$ Sun Printing \& Publ. Assin. v. Moore, loc. cit. supra note 67.

${ }^{2}$ Clement v. Cash (I860) 2x N. Y. 253, 257.

${ }^{80}$ (1907) 121 App. Div. 786, 790, т06 N. Y. Supp. 593, 596.

${ }^{81}$ Streeper $v$. Willians (1865) $48 \mathrm{~Pa} .450,454$. 
weight to the language of the clause designating the sum as a penalty or as liquidated damages. The modern authorities attach greater importance to the meaning and intention of the parties; yet the intention is not all-controlling, for in some cases the subject matter and surroundings of the contract will control the intention where equity absolutely demands it."

In Giesecke v. Cullerton, ${ }^{82}$ Chief Justice Carter, after saying that no branch of the law is involved in more obscurity by contradictory decisions than whether sums specified in an agreement to secure performance will be treated as liquidated damages or a penalty declared that "each case must depend upon its own peculiar and attendant circumstances, and that therefore general rules of law on the subject are often of a very little practical utility. While the intention of the parties must be taken into consideration, the language of the contract is not conclusive. The courts of this State, as well as in other jurisdictions, lean towards a construction which excludes the idea of liquidated damages and permits the parties to recover only the damages actually sustained. . . . The great weight of authority in this and other jurisdictions is based upon the principle that a stipulated sum will not be allowed as liquidated damages unless it may be fairly allowed as compensation for the breach." The courts of Illinois have done their full share of wabbling on this question, but the above deliverance is the last pronouncement and is in harmony with the modern current of the decisions.

The opinion held by the Supreme Court of Texas ${ }^{83}$ should find a place in this too brief review. If the damages are in their nature uncertain, or their amount indeterminate, the sum specified is treated as fixing by stipulation the amount of the recovery. That is in harmony with the general rule. "But the difficulty arises in cases in which the damages are reasonably susceptible of ascertainment." After remarking that it would seem that if the expressed intention of the parties to a contract should be given in every case, yet the principle would appear to be, that although a sum be named as liquidated damages the courts will not so treat it, unless it bear such proportion to the actual damages that it may reasonably be presumed to have been arrived at upon a fair estimation by the parties of the compensation to be paid for the prospective loss."

The courts that have shown the strongest inclination to enforce the intention of the parties as expressed in their agreements, in harmony with the federal courts, are Massachusetts, Maine, and Ohio. ${ }^{84}$ Thus, in Guerin v. Stacy Chief Justice Holmes says :85 "But we heartily agree

(I917) 280 Ill. 510, 513, II7 N. E. 777, 778.

${ }^{33}$ Collier v. Betterton (I895) 87 Tex. 442, 29 S. W. 467.

${ }^{84}$ Garst v. Harris (1900) I77 Mass. 72, 58 N. E. 174; Dreinel v. Brown (1867) 54 Me. 468; Knox Rock Blasting Co. v. Grafton Stone Co. (Igor) 64 Ohio St. $36 \mathrm{I}, 60 \mathrm{~N}$. E. 563 .

${ }^{85}$ (1900) I75 Mass. 595, 596, 56 N. E. 892. 
with the Court of Appeals in England that so far as precedent permits, the proper course is to enforce contracts according to their plain meaning and not to undertake to be wiser than the parties, and therefore that in general where parties say that a sum is payable as liquidated damages they will be taken to mean what they say and will be held to their word. Wallis v. Smith, 2I Ch. D. 243. Atkyns v. Kinnier, 4 Exch. 776, 783. In the language of Baron Parke in the case last cited, 'If there be a contract consisting of one or more stipulations, the breach of which cannot be measured,' as in theory of law the damage caused by the failure to pay money can be, 'then the parties must be taken to have meant that the sum agreed on was to be liquidated damages and not a penalty." "

A final reflection may be added on the action of the courts in thus setting aside so freely the intentions of the parties expressed in this class of agreements, while they are so mindful universally to ascertain and enforce them save in exceptional cases in all other classes. In thus enforcing them in conformity with justice do they not carry out the real intentions of the parties, not indeed as expressed in words, but quite as real as if they were thus expressed? These writings are usually drawn by lawyers who are familiar with the rules of law we have had under review. If the parties concerned had drawn their agreements themselves, very likely the measure of damages would have received greater consideration. But in the light of the rules of law, stated to them by their lawyers, that any large variation of damages that might be sustained, beyond the amount fixed, would be ascertained by the court if the parties themselves could not agree on the amount, the old phrases and forms have still been continued in use. Why have they not been changed? Because doubtless nothing better can be invented. While it is true that the courts do remake many of these contracts, they are doing, after all, only what the parties expect will be done whenever they themselves fail to agree on the damages that must be paid as a consequence of not fulfilling their contracts. Is not the criticism of Chief Justice Holmes in the Guerin case, ${ }^{86}$ above mentioned, without any real foundation? Are not the courts, who are executing the real deeper intentions of the parties rather than the bald literal ones expressed in writing, fully justified in so doing by a long course of decisions and by the expectation of all who are concerned in preparing and executing such agreements?

${ }^{86}$ Supra note 85 . 